Surgical Anatomy and Technique

Fourth Edition 

Lee J. Skandalakis

John E. Skandalakis

Editors

\section{Surgical Anatomy and Technique}

A Pocket Manual

Fourth Edition

With contributions by Panagiotis N. Skandalakis

望 Springer 


\author{
Editors \\ Lee J. Skandalakis, MD, FACS \\ Centers for Surgical Anatomy \\ and Technique \\ Emory University School \\ of Medicine \\ Piedmont Hospital \\ Atlanta, GA, USA
}

\author{
John E. Skandalakis, MD, FACS \\ Centers for Surgical Anatomy \\ and Technique \\ Emory University School \\ of Medicine \\ Piedmont Hospital \\ Atlanta, GA, USA
}

ISBN 978-1-4614-8562-9

ISBN 978-1-4614-8563-6 (eBook)

DOI 10.1007/978-1-4614-8563-6

Springer New York Heidelberg Dordrecht London

Library of Congress Control Number: 2013949138

(C) Springer Science+Business Media New York 1995, 2000, 2009, 2014

This work is subject to copyright. All rights are reserved by the Publisher, whether the whole or part of the material is concerned, specifically the rights of translation, reprinting, reuse of illustrations, recitation, broadcasting, reproduction on microfilms or in any other physical way, and transmission or information storage and retrieval, electronic adaptation, computer software, or by similar or dissimilar methodology now known or hereafter developed. Exempted from this legal reservation are brief excerpts in connection with reviews or scholarly analysis or material supplied specifically for the purpose of being entered and executed on a computer system, for exclusive use by the purchaser of the work. Duplication of this publication or parts thereof is permitted only under the provisions of the Copyright Law of the Publisher's location, in its current version, and permission for use must always be obtained from Springer. Permissions for use may be obtained through RightsLink at the Copyright Clearance Center. Violations are liable to prosecution under the respective Copyright Law.

The use of general descriptive names, registered names, trademarks, service marks, etc. in this publication does not imply, even in the absence of a specific statement, that such names are exempt from the relevant protective laws and regulations and therefore free for general use.

While the advice and information in this book are believed to be true and accurate at the date of publication, neither the authors nor the editors nor the publisher can accept any legal responsibility for any errors or omissions that may be made. The publisher makes no warranty, express or implied, with respect to the material contained herein.

Printed on acid-free paper

Springer is part of Springer Science+Business Media (www.springer.com) 
Dedicated to my father John Skandalakis who has reached out from the grave to provide valuable assistance for this edition. 



\title{
Preface to the Fourth Edition
}

\author{
"They will soar on wings like eagles; \\ they will run and not grow weary, \\ they will walk and not be faint."
}

\section{ISAIAH 40:31}

In this fourth edition of Surgical Anatomy and Technique: a Pocket Manual, several chapters were revised and a new chapter has been added. In the chapter on the abdominal wall and hernias, operating room strategies have been updated and techniques of historical interest only have been removed. A major addition to the chapter is a section on the anatomy and principles of component separation. The chapter on the pancreas was brought up-to-date by Drs. Harrison S. Pollinger and Marty T. Sellers with the addition of laparoscopic pancreatectomy. Any techniques that involve the use of the Harmonic Scalpel or the LigaSure have been updated to reflect those instruments. Much credit goes to Dr. Monica A. Hum, who did a major revision of the longest chapter in this book, Colon and Anorectum. This revamp involved extensive rewriting; I am most appreciative of her thoughtful emendation.

In the liver chapter, Dr. Marty T. Sellers clarified for all of us the segmental anatomy of this organ. Dr. Eyal Ben-Arie made some very useful additions to the treatment of the vascular system through vascular access procedures. Dr. John G. Seiler III completely revised the carpal tunnel chapter. We have also added an additional chapter, Miscellaneous Procedures, which includes subclavian vein catheter insertion, chest tube insertion, and sural nerve and muscle 


\section{viii Preface to the Fourth Edition}

biopsies. I am delighted that we were also able to include a new chapter on Bariatric Surgery written by doctors Kevin McGill and Charles Procter. This material is timely considering the ranks of the morbidly obese are increasing daily.

We have tried again to present what are considered to be basic surgical techniques. As more surgeons train in laparoscopic surgery, what were once considered advanced laparoscopic techniques have now become basic laparoscopic techniques. It is for this reason that I felt compelled to ask Dr. Pollinger to add the section on a laparoscopic pancreatectomy. Though many might consider it to be an advanced technique, the actual mechanics of removing the distal pancreas laparoscopically do not differ from performing this procedure in an open fashion. What is different is the placement of ports and the positioning of the patient in concert with "advanced" laparoscopic instruments and devices. Once again, if a suture is mentioned, it is only a suggestion. As we all know, there are many alternatives to various suture materials.

Though the senior and principal author (JES) passed away in 2009 he continues to influence this and future editions of this text. He is sorely missed.

Atlanta, GA, USA

Lee J. Skandalakis, MD, FACS 


\section{Acknowledgments}

I am truly privileged to have been allowed to revise Surgical Anatomy and Technique: a Pocket Manual. The associates at Springer Science+Business Media have made everything easy. I appreciate the faith and confidence that Richard Hruska, Senior Editor of Clinical Medicine, placed in me by greenlighting this project. Andy Kwan, Editorial Assistant, provided crucial assistance at the beginning of the revision.

Originally, I had my doubts about allowing illustrations to be executed inhouse at Springer. I just did not see how it would be possible to create a finished product without sitting down with the illustrators and explaining what we needed, then having them give me something a few days later, etc. Connie Walsh, Developmental Editor, worked with Carol Froman, Senior Editor, Department of Surgery, Emory University School of Medicine, so that the production of this book (including the illustrations) proceeded seamlessly. Truthfully, if it were not for Carol there would not be a revised edition. Phyllis Bazinet and Cynthia Painter provided editorial support at Emory for previous editions.

I would like to thank Dr. Christian P. Larsen, who was the Chairman of the Department of Surgery at Emory, for throwing his support behind this project and allowing it to go forward. Emory University School of Medicine is in good hands with Chris as the newly appointed Dean. I wish him the best.

Finally, I would like to thank Dr. Panagiotis G. Skandalakis for his great ideas for this book and the wonderful illustrations that kick-started this entire endeavor. 



\section{Contents}

Preface to the Fourth Edition ............................................................ vii

Acknowledgments.................................................................... ix

1 Skin, Scalp, and Nail.......................................................................

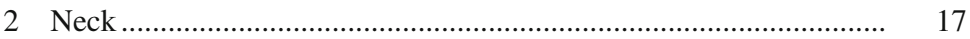

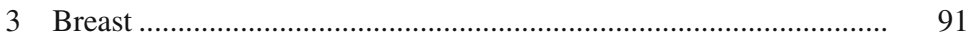

4 Abdominal Wall and Hernias ............................................................ 113

5 Diaphragm................................................................................ 217

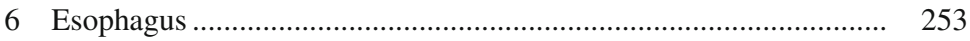

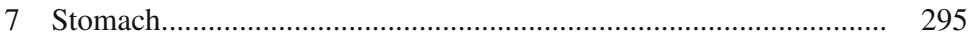

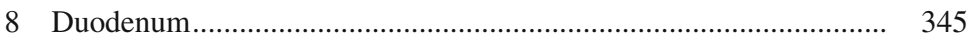

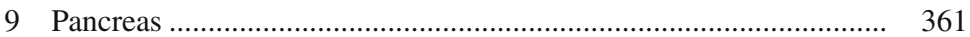

10 Small Intestine …...................................................................... 405

11 Appendix ............................................................................. 419

12 Colon and Anorectum .................................................................. 431

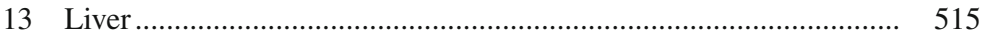

14 Extrahepatic Biliary Tract .......................................................... 565 


\section{xii Contents}

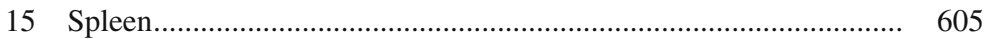

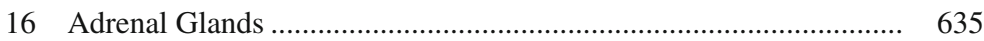

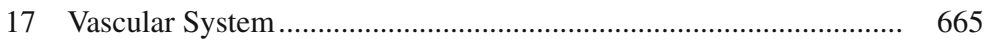

18 Uterus, Tubes, and Ovaries ………………………………………. 689

19 Carpal Tunnel............................................................................. 703

20 Microsurgical Procedures ................................................................ 715

21 Miscellaneous Procedures.............................................................. 723

22 Bariatric Surgery ....................................................................... 727

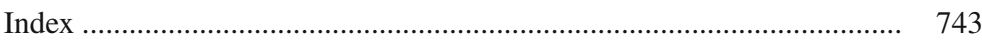




\section{Contributors}

Eyal Ben-Arie, MD

Piedmont Heart Institute

Piedmont Hospital

Atlanta, GA, USA

J. Dewayne Colquitt, MD, FACS

Department of Surgery

Piedmont Hospital

Atlanta, GA, USA

Seth D. Force, MD

Department of Surgery

Emory University

School of Medicine

Atlanta, GA, USA

Monica A. Hum, MD, FACS, FASCRS

Atlanta Colorectal Surgery

Atlanta, GA, USA

Kevin McGill, MD, FACS

Buckhead Bariatrics

Piedmont Hospital

Atlanta, GA, USA 


\section{xiv Contributors}

\section{Daniel L. Miller}

Department of Surgery

Emory University School of Medicine

Atlanta, GA, USA

\section{Petros Mirilas, MD, MSurg, PhD}

Centers for Surgical Anatomy \& Technique

Emory University School of Medicine

Atlanta, GA, USA

\section{Deepak G. Nair, MD}

Sarasota Vascular Specialists

Sarasota, FL, USA

\section{Harrison Scott Pollinger, DO, FACS}

Piedmont Transplant Institute

Piedmont Hospital

Atlanta, GA, USA

Charles D. Procter, Jr., MD, FACS

Buckhead Bariatrics

Atlanta, GA, USA

John Gray Seiler, III, MD

Georgia Hand, Shoulder \& Elbow

Atlanta, GA, USA

\section{Lee J. Skandalakis, MD, FACS}

Centers for Surgical Anatomy and Technique

Emory University School of Medicine

Piedmont Hospital

Atlanta, GA, USA

John E. Skandalakis, MD, FACS

Centers for Surgical Anatomy and Technique

Emory University School of Medicine

Piedmont Hospital

Atlanta, GA, USA

\section{Marty T. Sellers, MD, MPH}

Piedmont Transplant Institute

Piedmont Hospital

Atlanta, GA, USA 
C. Daniel Smith, MD

Department of Surgery

Mayo Clinic

Jacksonville, FL, USA

Robert B. Smith, III, MD, FACS

Emory University School of Medicine

Atlanta, GA, USA

Ramon A. Suarez

Emory University School of Medicine

OB/GYN Education, Obstetrics and Gynecology

Piedmont Hospital

Atlanta, GA, USA 